\title{
FUTURYSTYCZNA UCZTA LITERACKA (WŁADIMIR SOROKIN, MAHAPAГA)
}

\author{
FUTURISTIC LITERARY FEAST \\ (VLADIMIR SOROKIN, MANARAGA)
}

\section{ALEKSANDRA ZYWERT}

\begin{abstract}
AвSTRACт. In his latest novel Manaraga (2017) Sorokin comments on one of the most significant problems of modern times - the results of the anticipated death of the printed book as well as the related opposition between the original and the copy. The biggest problem, as the author suggests, is not the form of the already published literary classics but the absence of new classics, which can embrace ideas capable of awaking the humankind from its zest for comfort and motivating people for constructive progress.
\end{abstract}

Keywords: Vladimir Sorokin, Manaraga, book, feast, future

Aleksandra Zywert, Uniwersytet im. Adama Mickiewicza w Poznaniu, Poznań - Polska, olazywert@o2.pl

ORCID ID: 0000-0002-9922-6717

Władimir Sorokin, uważany za jednego z najbardziej radykalnych współczesnych pisarzy rosyjskich, należy do twórców żywo reagujących na aktualne, palące problemy współczesnego świata. Od jakiegoś czasu, o czym sam wspomina, zmienił nieco optykę widzenia i postanowił oceniać teraźniejszość przez pryzmat przyszłości. Sorokin mówi: „B Опричнике и Телчрии я нашел площадку обозрения мира настоящего через будущее" [2017b]. W najnowszej swojej książce Манарагa (2017), ocenianej przez samego autora jako wesoła i awanturnicza, Sorokin odnosi się do jednego z chyba najczęściej ostatnio komentowanych w różnych środowiskach (od twórczych poprzez biznesowe, aż po naukowe) zagadnień (choć jego, jak sam twierdzi, nie dotyczącego. Sorokin mówi: „У меня старомодное отношение к книге. Я люблю ее вес, шершавость страниц, запах. На книгу можно пролить кофе или даже поставить горячий кофейник, можно прожечь ее сигаретой. Она молчит, ей не нужно электричества. Она ничего не требует. Хочешь - читай, хочешь - поставь на полку, хочешь - выброси на помойку. Ее можно облить слезами, вином, кровью, спермой. И это все останется на ней в память о читателе. В нее можно вложить цветок. Когда я был в Стэнфорде, то там, в библиотеке, читал дневники русских офицеров, 
покинувших Россию сразу после Гражданской войны. У одного офицера дневник кончался, когда он садился на корабль в Одессе. И на последней странице была веточка акации. А что может $\mathrm{iPad}$ ? Слезы или кровь стекут с него, ничего не оставив" [2016]), a mianowicie prognozowanej śmierci tradycyjnych książek i pojawiającego się na tym tle problemu relacji oryginał-kopia (jednoznacznie nawiązującego do zagadnienia symulacji i symulakrów). Temat ten nie jest zupełnie nowy, bo motyw słowa pisanego w różnych wariacjach pojawiał się już w jego twórczości [jak choćby w powieści Роман (1985-1989), Голубое сало (1999), czy sztuce Concretные (2000)], stanowiąc swego rodzaju autorski komentarz, głównie dotyczący kwestii rosyjskiego literaturocentryzmu. Autor od początku swojej działalności opowiadał się za zniesieniem społecznej funkcji literatury, a zatem i zmiany statusu pisarza z nauczyciela, wieszcza i guru na zwykłego skryptora [Генис 2016]. W tym znaczeniu Maнарагa jest kolejnym głosem w dyskusji o wciąż ewoluującym świecie, tak więc nie dziwi fakt, że wiele rozwiązań czy chwytów zostało zapożyczonych z wcześniejszych utworów.

Akcja rozgrywa się w enigmatycznej, dalekiej przyszłości. Dokładna data nie jest podana, ale można się domyślać, że jest mniej więcej rok 2060. Pozornie wydaje się, że Sorokin zachowuje chronologię czasową - przedstawiony okres jest kolejną fazą naszkicowanego już wcześniej [poczynając od Dnia орrусznika (День опричника, 2006) poprzez Cukrowy Kreml (Сахарный Кремль, 2008), aż po Tellurię (Теллyрuя, 2012)], ale tak nie jest. De facto autor żongluje czasem, cofa się i wypełnia lukę pomiędzy czasem powieści Голубое caлo rokiem 2068.

Nowe Średniowiecze ewoluowało w dziwaczny, momentami groteskowy Renesans: po drugiej fali rewolucji islamskiej Europa Zachodnia częściowo jest opanowana przez muzułmanów (bodaj jedynym niezależnym krajem jest Szwajcaria, która obroniła swój status, korzystając z pomocy pakistańskich legionistów), a częściowo podzielona na mnóstwo maleńkich księstewek, zaś na Uralu funkcjonuje niezależna republika zasiedlona głównie przez Chińczyków. Praktycznie zniknęły narody (niemal każdy obywatel nowego świata jest mieszanką genetyczną różnych), Rosja straciła swoją pozycję światowego lidera, a język rosyjski prawie zanikł („встретить русскоговорящего человека теперь уже трудно. Я помню русских только в детстве, когда они приезжали к нам в Будапешт за работой" [Сорокин 2017a: 21]). Organizacja życia społecznego to konglomerat reaktywacji średniowiecznego okrucieństwa (publiczne egzekucje, kaźnie) z jeszcze bardziej agresywnie, niż w poprzednich utworach, ingerującymi w osobowość człowieka osiągnięciami myśli technicznej. W świecie przyszłości codziennością są filmy holograficzne, żyworodne futro i cyborgi - ludzie z wszczepionymi do mózgu elektronicznymi pchłami zawierającymi wszelkie dostępne dane z różnych 
dziedzin nauki. Symbioza człowieka z maszyną jest do tego stopnia posunięta, że niebezpiecznie zbliża się on do postrzegania samego siebie jako organizmu postbiologicznego - integralnego elementu cyberprzestrzennej cywilizacji, niebędącego w stanie funkcjonować poza systemem kolektywnego mózgu [Zawojski 2002: 423-431].

Pojęcie druku jest $\mathrm{w}$ zaniku, bo jedyną ciągle produkowaną $\mathrm{w}$ ten sposób rzeczą są pieniądze („Эпоха Гутенберга завершилась полной победой электричества. В нашем мире продолжают печатать только деньги [...]. В отличие от книг, деньги плохо горят. Поэтому на них и не жарят" [Сорокин 2017a: 15]), zaś tradycyjnie wydawane książki już dawno odeszły w przeszłość i zostały zastąpione cyfrowymi. $W$ tym świecie rozwija się bardzo intratny, acz niebezpieczny nielegalny biznes - book'n' grill, czyli gotowanie na palących się książkach (najchętniej na pierwodrukach).

Główny bohater - mistrz kucharski Geza, członek podziemnego klanu kucharzy, od lat już gotuje wyszukane dania na płonących dziełach, ale zdaje sobie sprawę, że w pewnym momencie ich zabraknie. Wyjściem z impasu ma być, firmowany przez część klanu, projekt maszyny zdolnej klonować na poziomie molekularnym dowolny pierwodruk znanego dzieła literatury światowej. Będzie to początek zupełnie nowej ery, ery namacalnego powszechnego komfortu, ale i (w obliczu zwycięstwa kopii nad oryginałem) ostatecznego końca book'n' grilla.

Tytuł powieści to nazwa jednej z najciekawszych i jednocześnie najmodniejszych ostatnio (między innymi z uwagi na niezwykły kształt) gór północnego Uralu [zob. Подкорытов 2015]. W jej czeluściach autor umieścił tajną wytwórnię molekularnych kopii pierwodruków najcenniejszych dzieł literatury światowej. Przypomnijmy, że bardzo podobne rozwiązanie zostało zastosowane już wcześniej we wspomnianej już powieści Голубоe caлo, w której tajne laboratorium produkujące klony światowej sławy pisarzy i poetów znajdowało się w podobnym miejscu. Tam jednak, by wyprodukować tekst, potrzebny był „duplikat” autora, tu autor poszedł dalej i pokazał, że w obliczu błyskawicznego rozwoju technologicznego ten ostatni jest już całkowicie zbędny.

Połączenie znanych motywów (śnieg/lód i klonowanie) w jakościowo nowym układzie pozwala wysnuć wniosek, że z uwagi na swoją funkcję w powieści - miejsce narodzin ",autentycznej kopii” - góra Manaraga zyskuje status symbolu uosabiającego filozoficzny paradoks Kota Schrödingera (wyprodukowana książka jest jednocześnie autentykiem i kopią), ale w powiązaniu z wymową ideową całości utworu może być także postrzegana jako nowa wersja Kuprinowskiego molocha - grobu wszelkiej kultury.

Struktura budowy świata przedstawionego $\mathrm{w}$ dużym stopniu wynika $\mathrm{z}$ architektoniki powieści. Całość tekstu jest podzielona na dwanaście styli- 
zowanych na pamiętnik części i obejmuje okres czasu (co zaznaczono w tytułach) od 13 marca do 12 kwietnia. Z uwagi na tempo akcji utwór można podzielić na dwie, nierównomierne pod względem objętości, części. Pierwszą tworzy 11 dość statycznych opisów kolejnych podróży i kulinarnie wyrafinowanych show, realizowanych na zlecenie bogatych, acz niezbyt rozwiniętych intelektualnie klientów, którzy są gotowi słono płacić za absurdalny kontakt ze strawą duchową. Przełomem jest dopiero ostatni rozdział, w którym następuje gwałtowne przyspieszenie - dochodzi w nim do dramatycznego starcia Gezy z rzecznikami nowej technologii.

Tego rodzaju rozłożenie akcentów doskonale wpisuje się w autorską strategię wyeksponowania momentu przemiany świata już uporządkowanego i już oswojonego w całkowicie nieznany. Z tego względu przez lwią część powieści autor „idzie” za bohaterem, a nie za wydarzeniami, by dopiero w ostatnim rozdziale gwałtownie przenieść punkt ciężkości i wyeksponować element dramatyczny - początek końca rozwoju ludzkości.

Niebagatelną rolę odgrywa tu sposób konstrukcji narratora. Pierwszoosobowy narrator jest jednocześnie głównym bohaterem utworu i spełnia rolę przewodnika dla odbiorcy. Nie rysuje on szerokiej, obiektywnej panoramy świata, a pokazuje go niejako "od kuchni”, spokojnie przedstawia zarys sposobu jego funkcjonowania, mechanizmy nim sterujące i wyodrębnia w nim tylko te fragmenty, które uważa za istotne. Świadoma sugestywność i subiektywna selekcja informacji sprawia, że czytelnik jest płynnie wprowadzany w meandry nowej rzeczywistości tak, aby był w stanie wyważyć proporcje i wyłowić jej cechy wywoławcze. Jest to o tyle istotne, że świat Manaragi jest jakościowo zmodyfikowaną, ale jednak kontynuacją rzeczywistości zaprezentowanej już wcześniej (poczynając od Dnia oprycznika), a oprócz tego zawiera wszystkie stałe motywy twórczości pisarza takie jak: jedzenie, śnieg/ lód, Chiny, narkotyki. Wszystkie te elementy nie funkcjonują jednak na zasadzie prostego przeniesienia, bo są uzupełnione o kolejne, wynikające z nowej interpretacji, treści naddane ${ }^{1}$. Wiąże się to ze zmianą jądra zainteresowania autora, który tym razem analizuje kondycję ludzkości w obliczu następnego, nieuchronnego zwrotu kulturowego, a ściślej (biorąc pod uwagę wymowę ideową powieści) antykulturowego. Widać to wyraźnie na podstawie analizy konkretnych motywów.

Pierwszy z nich, najbardziej oczywisty - to jedzenie. Początkowo funkcjonujący tylko jako synonim pochłaniania, niszczenia, bardzo szybko zyskiwał kolejne znaczenia, zwłaszcza, że został trwale połączony z elementami dotyczą-

${ }^{1}$ Strategia ta stała się przyczyną niejednoznacznego odbioru powieści. Niektórzy krytycy właśnie z tego względu potraktowali ją jako wtórną w kontekście całości twórczości Sorokina [zob. np. Карпачев 2000-2012; Самойлов 2000-2012; Владимирский 2013]. 
cymi sztuki kulinarnej. Po raz pierwszy motyw ten w klarownej formie pojawił się w utworach takich jak Норма (1979-1984) і Роман (1985-1989) i właściwie w tym samym okresie (mowa o sztuce Пельмени - wersja z 1986 roku) zyskał status elementu trwale połączonego z transgresją. Wówczas jednak był nieco inaczej eksponowany niż w ostatnim okresie. „Wcześniejszy” Sorokin jeszcze chętnie posiłkował się poetyką horroru, kładł nacisk na fizjologię i transformację ciała, zaś mniej na nieco łagodniejszą metodę budowania metafory. Ta słynna już dziś kulinarna szokoterapia była z powodzeniem kontynuowana w powieści Голубое caлo i zbiorze opowiadań Пир (2000) [ze szczególnym uwzględnieniem opowiadania Жрать - swoistej kulminacji metafizyki jedzenia). Jednocześnie od połowy lat 90 . XX wieku proces jedzenia został połączony z motywem przestępstwa (sztuka Щu (1995)]. W tym kontekście prezentowana w Manaradze wizja może być kwalifikowana jako kolejna faza jego (jedzenia) ewolucji. Sorokin łączy w niej wszystkie dotychczas prezentowane warianty metaforycznego odczytywania jedzenia, dodatkowo łącząc je z problemem opozycji oryginał-kopia w kontekście realizowanego od początku twórczości problemu wchłaniania/pożerania/niszczenia kultury. Szczególnie wyraźnie widać to na przykładzie sposobu materializacji metafor takich pojęć jak „,czytanie", ,"czytelnik", „strawa duchowa” czy "głód książek".

Jednym z lepszych przykładów tego zjawiska jest opis uczty mieszkańca piramidy w Alpach Szwajcarskich, gigantycznego zoomorfa. Posiłek jest przygotowywany na rękopisie napisanego własną krwią przesłania gospodarza, zaś będące jego podstawą mięso jest z jego lewej piersi. Klient Gezy jest zadziwiającą hybrydą człowieka i zwierzęcia, która mieni się samozwańczym wcieleniem bóstwa, nowym Nietzsche, pragnącym poprzez aufofagię zrealizować swoją ideę nadczłowieka, zdolnego przezwyciężyć wszelkie ograniczenia, a w rzeczywistości jest tylko groteskowym grafomanem. $W$ finale tej rytualnej uczty olbrzym zjeżdża z góry na snowboardzie z napisem „DIE GROSSE WENDE" [Сорокин 2017a: 142].

Absurdalny, groteskowy i śmieszny w gruncie rzeczy, skonstruowany według charakterystycznego dla Sorokina chwytu gwałtownej zmiany stylu, finał biesiady $\mathrm{z}$ jednej strony kończy temat obecnych już od dość dawna (choćby w zbiorze Пup) tajemniczych zoomorfów, z drugiej, w szerszej perspektywie, wpisuje się w autorską ocenę współczesnej (nienajlepszej jego zdaniem) kondycji literatury klasycznej - kiedyś inspiracji do intelektualnych rozważań, dziś - pozbawionego jakiejkolwiek głębszej refleksji symbolu statusu materialnego.

Pogląd ten przekłada się na konstrukcję głównego bohatera. Geza, choć uważa się za romantyka i tradycjonalistę, pod każdym względem jest produktem swoich czasów. Ten trzydziestotrzyletni człowiek, urodzony w Budapeszcie syn białoruskiego Żyda i polskiej Tatarki, czujący się spadkobier- 
cą kultury wysokiej, de facto tylko doskonale wpisuje się w potrzeby rynku, fundując klientom atrakcyjne widowisko. I choć Geza zapewnia, że jest to coś więcej niż tylko gotowanie i rytualizuje jego przebieg przy pomocy różnych gadżetów (jako mistrz ceremonii ma na głowie charakterystyczną czapkę, jest także "uzbrojony" w specjalny przyrząd zwany Excaliburem, którym przewraca kolejne kartki), niczego to nie zmienia, bo ostatecznie i tak jego praca nie jest misją i nie stanowi przeciwwagi dla, nastawionego na łatwe i szybkie odczucie komfortu, świata.

Книги для меня не просто дрова, как их называют в нашем поварском подпольном сообществе. Все-таки книга - это целый мир, хоть и ушедший навсегда. В этом смысле я романтик. Я сын гуманитария, внук стоматолога, правнук адвоката, праправнук раввина. И я знаю точно - если ты любишь книгу по-настоящему, она отдаст тебе все свое тепло [Сорокин 2017а: 10].

Sporą rolę pełnią w nim narkotyki. Nie jest to już kokaina (jak w Dniu oprycznika) czy cukier (jak w Cukrowym Kremlu), a elektroniczne pchły, które wszczepione na stałe do mózgu są w stanie trwale uzależnić od siebie człowieka, rozleniwić, sztucznie uszczęśliwić i tym sposobem skutecznie pozbawić go jakiejkolwiek indywidualności. Jak zauważa sam autor, są to: „Hoвые паразиты, которые не просто сосут кровь, но и наполняют человека информацией и уверенностью в себе... Такая блоха, которая подковала человека!" [Сорокин 2017b]. Widać wyraźnie, że w tym przypadku modyfikacja motywu jest tylko czysto powierzchowna, ponieważ funkcja i znaczenie narkotyków pozostaje nietknięta [Липовецкий 2013]. Bezpośrednią przyczyną jest fakt, że świat $w$ dalszym ciągu jest opanowany przez totalitaryzm $\mathrm{z}$ tą jednakże różnicą, że tym razem jest to totalitaryzm przymusu nowego wymiaru komfortu psychicznego, polegającego na programowej eliminacji jakiegokolwiek wysiłku intelektualnego człowieka.

Ciekawe w tym kontekście rozwiązanie zastosował autor w przypadku motywu Chin. Funkcjonując od początku jako symbol niebywałej zdolności do asymilacji i związanego z nią przemożnego ekspansjonizmu, wyrażającego się przede wszystkim w skutecznym niszczeniu rosyjskiej pamięci kulturowej i zastępowaniu jej kulturą ahistoryczną, tym razem znalazł się on na dość dalekim planie [Zywert 2015: 265-274]. Wydaje się, że autor świadomie nie poświęcił mu zbyt wiele miejsca z uwagi na jego jednoznaczne i wielokrotnie już utrwalone konotacje. Lokalizacja wytwórni surogatów w "chińskiej” części świata jest oczywista i automatycznie przywołuje na myśl skojarzenia Chin jako państwa zdolnego wchłonać, przyswoić i przekształcić wszelkie technologie - światowego królestwa podróbek.

Uzupełnieniem strategii artystycznej żonglerki literaturą jest obecność (podanych w mniej lub bardziej zawoalowanej formie) odwołań do twórczo- 
ści autora (np. „Блоха идентифицирует оперу: The Children of Rosenthal” [Сорокин 2017a: 186]) oraz innych, światowej sławy znakomitości pisarskich, jak np.: wariacja na temat wiersza Michaiła Lermontowa Выхожу один я на дорогу (1841). Pierwsza zwrotka tego utworu, która u Lermontowa brzmi: „Выхожу один я на дорогу / Сквозь туман кремнистый путь блестит / Ночь тиха. Пустыня внемлет богу / И звезда с звездою говорит" [1988], u Sorokina zostaje następująco przetworzona: „Под возбужденный писк соскучившихся блошек выезжаю один я на дорогу. И блоха с блохою говорит" [2017a: 132]. Znajdujemy też nawiązanie do słynnej Bułhakowowskiej frazy "rękopisy nie płoną" - Geza przylatuje na Sachalin, by przyrządzić dla grupy aktorów sandacza na Mistrzu i Małgorzacie (Macmep u Mapzapuma, 1929-1940). Nieoczekiwanie okazuje się, że egzemplarz powieści Bułhakowa jest wilgotny i mimo wysiłków kucharza nie udaje się zrealizować zlecenia.

Parodiowanie klasyków - kolejna cecha charakterystyczna pisarstwa Sorokina - znajduje swoje odzwierciedlenie także choćby we wplecionej w tekst główny noweli Tołstoj, będącej przewrotną interpretacją filozofii Lwa Tołstoja. Jej głównym bohaterem jest wielkolud Tołstoj, który każdej wiosny przychodzi do wsi zwiastować jej nadejście. Tołstoj - upostaciowanie dobrotliwego i opiekuńczego „ojczulka” - i tym razem przychodzi do wsi, by oświecić i wesprzeć „swój” ciemny lud: opowiada wieśniakom przypowieść o maleńkiej pchle, a na zakończenie wyciąga z kieszeni malutkiego mamuta, który śpiewa Love me tender Elvisa Presleya. Tego rodzaju „uszczelnianie” świata znacząco wpływa na proces jego odczytywania i rozumienia utworu, zapewniając tym samym ciągłość refleksji w kontekście całości dokonań autora.

Punktem wyjścia do Sorokinowskich rozważań jest dominujący w całej powieści motyw palenia książek - element cyklicznie pojawiający się $\mathrm{w}$ historii ludzkości od momentu wynalezienia pisma. Jest jednak zasadnicza różnica motywacyjna: dotąd, jak wspomina Umberto Eco, immanentną częścią historii książek (niezależnie od okresu historycznego) było ich unicestwianie ze strachu przed siłą i władzą słowa pisanego, z chęci zniszczenia narodu poprzez zanik jego języka i żądzy ekspansji terytorialnej [Carrière, Eco 2010: 199-216]. W Manaradze tego strachu już nie ma, bo całkowicie zmienił się sposób funkcjonowania piśmienniczego uniwersum - tradycyjne książki stały się zbędnym, zajmującym zbyt dużo miejsca balastem i dlatego początkowo ich niszczenie było niczym więcej jak tylko zwykłym „sprzątaniem świata”, czyszczeniem go z przestarzałych technologicznie rzeczy. Pozornie, proces ten nie miał nic wspólnego z niszczeniem kultury, bo słowo nie zniknęło, a tylko przeszło na inny poziom funkcjonowania - w cyberprzestrzeń. Niemniej po jakimś czasie okazało się, że masowe unicestwienie artefaktów zaświadczających o „rewolucji Gutenberga” zaburzyło ciągłość historii i kultury, tworząc wyrwę, której ponowne zapełnienie jest niemożliwe. Koniec 
„kultury druku” oznacza więc koniec epoki kultury indywidualnej kreatywności, autentyczności, niepowtarzalności i wyjątkowości.

W tym znaczeniu kolejne, opisywane przez narratora-przewodnika, uczty mają podwójne znaczenie. $Z$ jednej strony to swoista sublimacja pragnienia komfortu, przyjemności i rozrywki w jej najbardziej podstawowym, bo kulinarnym, zmysłowym, smakowym wymiarze. Z drugiej - to symboliczny pokaz siły, bo oto stara kultura zostaje dosłownie strawiona przez ogień. Dokonując po raz kolejny spalenia książki, kucharz-rzecznik nowych czasów dokonuje de facto najbardziej oczywistego z totalitarnych aktów agresji. Nieodwracalna śmierć papierowej książki jest jeszcze dobitniejszą formą materializacji metafory, prezentowanej już między innymi w powieści Голубое caлo czy sztuce Concretныe, a odzwierciedlającej pogląd Sorokina o martwocie literatury rosyjskiej, z tą jednakże różnicą, że teraz autor poszedł dalej: ostatecznie spektakularnie „uśmiercił” nie tylko rosyjską klasykę, ale i całą literaturę światową. W analogiczny, bo niestandardowy sposób eksponowane i odczytywane są, trwale wpisane $\mathrm{w}$ rosyjską tradycję, symbole. Przykładem może służyć chociażby czapka kucharska Gezy. Będąc z jednej strony (także dzięki materiałowi, z którego jest wykonana - ferrosilikonu) namacalnym atrybutem władzy, współczesną wersją Czapki Monomacha, odsyła jednocześnie i do folkloru (czapka niewidka), i do powieści Michaiła Bułhakowa Mistrz i Małgorzata, by ostatecznie w finale utworu w mgnieniu oka rozpaść się na drobne kawałki, i zmienić w symbol porażki w starciu z prawami rynku.

Istotny w tym kontekście jest fakt, że w Sorokinowskim świecie pierwszym produktem przeznaczonym do masowej dystrybucji jest sklonowany pierwodruk Ady (Ada or Ardor: A Family Chronicle, 1969) Vladimira Nabokova. Jest on istotny $\mathrm{z}$ dwóch powodów. Po pierwsze, jest to jedna $\mathrm{z}$ ulubionych powieści Sorokina (o czym wielokrotnie wspominał w wywiadach), po drugie - daje autorowi możliwość rozszerzenia swoich rozważań pisarskich o kwestię kondycji literatury światowej. W tym znaczeniu pojawienie się maszyny będącej w stanie odtworzyć w dowolnej ilości pierwodruk wybranego dzieła na poziomie molekularnym nie tylko nie likwiduje problemu oryginału jako artefaktu ściśle powiązanego z ludzkim umysłem, ale wręcz go pogłębia, bo przekłada się ostatecznie na sposób funkcjonowania świata jako takiego. W tym kontekście strach, a potem walka części klanu/sekty kucharzy $\mathrm{w}$ imię ocalenia book'n' grilla, paradoksalnie urasta do rangi wojny o ocalenie autentyzmu rzeczywistości w obliczu realnego zagrożenia ekspansją klonów. Istotna jest tu rozmowa Andre z Gezą. Okazuje się, że sklonowana Nabokowowska Ada jest tylko początkiem ery zwycięstwa jawnie dehumanizującego systemu opierającego się na Ritzerowskiej nieracjonalności racjonalności [Ritzer 2012: 162-163]. Andre mówi: „«Ада» - лишь начало. Первый шар. Второй будет другим [...] «Дон Кихот». Первое издание, естественно. 
И другая конструкция печи [...] Третий продукт - «Улисс». Четвертый «Гаргантюа и Пантагрюэль»" [Сорокин 2017а: 228].

Sorokin pokazuje, że historia zatacza koło - najpierw ludzkość świadomie pozbywała się autentyzmu, potem do niego ponownie dążyła i się nim zachwycała, by znowu wpaść w pułapkę taniej podmiany, bo ostatecznym celem Andre i jego współpracowników jest legalizacja book'n' grilla i stworzenie dochodowej sieci restauracji.

Обеспеченная семья идет вечером в ресторан „Дон Кихот”. Другая - в „Улисс”. Третья - в „Процесс”. Вкусный обед из четырех блюд на первоизданиях. Короткое меню. Печь стоит возле стола, полюбуйтесь, дети, как горит великий роман. Дорогой, как это красиво! Тебе нравится, дорогая? Счет, пожалуйста. Все было вкусно? Да, благодарим вас. Приходите к нам еще [...]. Мы предъявляем высококачественный продукт. В любом бизнесе важно только качество продукта. Оно будет первосортным. Для властей - мы ничего не нарушаем. В музеях не убыло. Полиция отдыхает. Естественно, такие обеды будут стоить раз в двадцать дешевле, чем сейчас. Но и клиентов будет раз в тридцать больше. Реклама. Правильная. Причуда одиночек, ставшая массовой традицией. Без риска. Без гастрита и ревматизма [Сорокин 2017а: 230-231].

Oprócz problemu ekspansji symulakrycznej rzeczywistości, Sorokin pośrednio nawiązuje tu także do poruszonego przez Jeana Baudrillarda problemu konieczności sztucznej produkcji „popytu na sens” w sytuacji powszechnej dostępności dóbr konsumpcyjnych w połączeniu z zagadnieniem klonowania, postrzeganym jako uświęcenie powtarzalności tego samego w imię przezwyciężenia Freudowskiego heimlich/unheimlich, a więc urzeczywistnienia marzenia „o doskonałym podwojeniu bądź zwielokrotnieniu własnego istnienia” [Baudrillard 2005: 121; Baudrillard 2006: 39]. Widać tu, że motyw klonów i klonowania obecny w twórczości Sorokina od czasu pojawienia się powieści Голубое cano także ewoluował. O ile wcześniej autor bazował na motywie klonowania ludzi jako źródle tekstu, uznając ludzki umysł za element niezbędny do pojawienia się idei, tu dokonał jakościowej modyfikacji - pominął nie tylko twórcę, ale i sam proces tworzenia i w ten sposób zatrzymał człowieka w rozwoju. Wskazał, że zdolność do wyprodukowania idealnych podróbek płodów jego umysłu zwiększa, co prawda, dostępność konkretnych dóbr, ale jednocześnie staje się końcem ewolucji społeczności. Znaczący wpływ ma na ten proces także nakreślony w powieści projekt macdonaldyzacji społeczeństwa w oparciu o plan restauracji sieciowych jako formy jej uśmiercenia. Będą one efektywnym sposobem na monopolizację rynku i sukces finansowy ich twórców, ale jako integralna część procesu racjonalnego (a przez to skutecznego), spowodują śmierć book'n grilla, który, choć z jednej strony szkodliwy, jednak był systemem umagicznionym, a więc niepowodującym $\mathrm{w}$ dalszej perspektywie totalnej blokady kreatywności człowieka. Różnicę pomiędzy oboma systemami 
w kontekście skutków i zjawisk, jakie generują w społeczeństwie wyjaśnia George Ritzer: „Systemy umagicznione zwykle wymagają bardzo skomplikowanych środków do realizacji celu, bez względu na jego charakter [...]. Systemy skuteczne [...] nie pozwalają na takie bezkierunkowe działanie, a ich projektanci zrobią wszystko, żeby je wyeliminować" [Ritzer 2012: 166].

Uwzględniając powyższe uwagi $\mathrm{w}$ procesie analizy powieści Sorokina, można powiedzieć, że w pewien sposób odżywa w niej (choć już w zupełnie innych warunkach), opisana przed laty przez Jurija Oleszę w powieści Zawiść (3aßucmь, 1927), idea okiełznania, uzależnienia i ubezwłasnowolnienia społeczności poprzez giganta żywieniowego, serwującego tanie i smaczne, acz jakościowo wątpliwe produkty. Tego rodzaju fałszywa demokratyzacja dostępu do dóbr uważanych za luksusowe, podobnie jak wcześniej, także i tu powoduje dominację falsyfikatu nad autentykiem, a co za tym idzie, błyskawicznie pozbawia społeczeństwo zdolności do jakiegokolwiek progresywnego działania.

$\mathrm{W}$ tę koncepcję idealnie wpisuje się wybitnie antyutopijny finał powieści. Oto kucharz Geza, jeden z ostatnich (jak się w końcu okazuje) Mistrzów w swoim fachu, przegrywa. Klan kucharzy zostaje rozbity, czapka Mistrza roztrzaskuje się w drobny mak, zaś jej właściciel tonie w wirtualnych objęciach wietnamskich bliźniaczek. Śmierć kucharza (nieistotne, fizyczna czy symboliczna) jest aktem ostatecznie przypieczętowującym koniec pewnej epoki. To nie tylko koniec literatury, ale i całej kultury wysokiej (nawet $\mathrm{w}$ jej najbardziej szokującej, przewrotnej wersji) i w pewnym sensie człowieka w ogóle. Bo oto Geza - ostatni profesjonalista, ogniwo pomiędzy kulturą a plebsem, gotowym słono płacić za jej „doświadczanie”, zostaje wchłonięty (dosłownie i w przenośni) przez nowy świat, który nie szanuje już żadnych świętości i poprzez swoją nieograniczoną zdolność do powielania wszystkiego przekształca się w piekło na ziemi. Przyszłość tego świata, co dobitnie podkreśla autor, będzie de facto życiem w śmierci, bezsensownym trwaniem bez początku i bez końca. Proces transgresji się zakończył i fizjologia zwyciężyła kulturę.

Reasumując, wychodząc od odzwierciedlonego w sztuce Concretныe przekonania, że „Массы не делают культуру - они ее пожирают и переваривают. Культуру делают индивидуальности" [Сорокин 2002], Sorokin, jak się wydaje, kończy temat, prezentując sytuację wybitnie graniczną, wyjście poza którą będzie oznaczało definitywny brak możliwości powrotu do stanu poprzedniego. $Z$ drugiej strony wizja ta nie jest krańcowo pesymistyczna, bo przecież książki nie zniknęły, zmieniła się tylko forma ich istnienia i sposób funkcjonowania. O wiele bardziej negatywnym zjawiskiem jest brak indywidualności pisarskich. W powieści Sorokina współczesna literatura nie jest już płodem wybitnych umysłów, ale snobistycznych bogaczy (jak w przypadku epigona Lwa Tołstoja) bądź szaleńców (jak gigant zoomorf), którzy owładnięci obłędem potrafią tylko nieudolnie kopiować i deformować wcześniejsze 
idee. W rezultacie wciąż nośny, zwłaszcza w obliczu ekspansji cyberprzestrzeni, motyw palenia książek spełnia tu służebną rolę jako przyczynek do dyskusji nad pogłębiającą się atrofią intelektualną ludzkości - coraz bardziej wygodnej, znudzonej, umysłowo uśpionej. Głównym problemem, jak wskazuje Sorokin, nie jest forma funkcjonowania dotychczas istniejących dzieł, a brak nowych, wartościowych pozycji, które niosłyby ze sobą uniwersalne prawdy, idee zdolne obudzić rozleniwioną ludzkość i zmotywować ją do koncepcyjnego i kreacyjnego działania.

\section{Bibliografia}

Владимирский В. 2013. Мягкое порно Владимира Сорокина. О романе «Манарага» Владимира Сорокина, „Новое литературное обозиене” №120, źródło elektroniczne: http:/ / www.srkn.ru/criticism/myagkoe-porno-vladimira-sorokina.html (dostęp 6.09.2017).

Генис А. 2016. Обратный адрес. Автопортрет, Москва: АСТ, źródło elektroniczne: https:/ / mybook.ru/author/aleksandr-genis/obratnyj-adres-avtoportret/ (dostęp 15.05.2017).

Карпачев А. 2000-2012. Книга «Манарага», źródło elektroniczne: http://www.srkn.ru/ criticism/kniga-manaraga.html (dostęp 6.09.2017).

Лермонтов М. Ю. 1988. Сочинения 8 2-x томах, t. 1, Москва, źródło elektroniczne: http:/ / www.stihi-rus.ru/1/Lermontov/23.htm (dostęp 10.05.2017).

Липовецкий М. 2013. Сорокин-троп: карнализация, źródło elektroniczne: http:// magazines.russ.ru/nlo/2013/120/li11.html (dostęp 10.05.2017).

Подкорытов А. 2015. Царица Уральских гор, źródło elektroniczne: http:/ / www.nat-geo. $\mathrm{ru} /$ photo/100729/ (dostęp 10.6.2017).

Самойлов М. 2000-2012. Гора родила кулинарную книгу, źródło elektroniczne: http:/ / www.srkn.ru/criticism/gora-rodila-kulinarnuyu-knigu.html (dostęp 6.09.2017).

Сорокин В. 2002. Убойное сало. Беседу вела Оксана Семенова, źródło elektroniczne: http:/ / www.mk.ru/old/article/2002/07/21/164539-uboynoe-salo.html (dostęp 15.02.2017).

Сорокин В. 2016. Постсоветский гротеск уже стал сильнее литературы. Беседовала Галина Юзефович, źródło elektroniczne: https:/ / esquire.ru/sorokin (dostęp 4.07.2017).

Сорокин В. 2017а. Манарага, Москва: АСТ.

Сорокин В. 2017b. «Симбиоз физиологии, шоу и моды», Владимир Сорокин о сожжении книг, счастье и новых гаджетах, Беседовала Наталья Кочеткова, źródło elektroniczne: https:/ /lenta.ru/articles/2017/03/06/manaraga/ (dostęp 10.05.2017).

Baudrillard J. 2005. Symulacja i symulakry, przeł. S. Królak, Warszawa: Sic!

Baudrillard J. 2006. W cieniu milczącej większości, przeł. S. Królak, Warszawa: Sic!

Carrière J.-C., Eco U. 2010. Nie myśl, że książki znikna, przeł. J. Kortas, Warszawa: W.A.B.

Ritzer G. 2012. Magiczny świat konsumpcji, przeł. L. Stawowy, Warszawa: Muza S.A.

Zawojski P. 2002. Monitory między nami. O byciu razem i osobno w cyberprzestrzeni, [w:] A. Gwóźdź, P. Zawojski (red.), Wiek ekranów. Przestrzenie kultury widzenia, Kraków: Rabid, s. 423-431.

Zywert A. 2015. Obraz Chin w twórczości Wtadimira Sorokina, [w:] J. Getka (red.), Europa Środkowo-Wschodnia w perspektywie interdyscyplinarnej, Warszawa: Akant, s. 265-274. 
